\title{
Association between Self-esteem Levels of University Female Students and Their Physical apperance, Physique and Body Language
}

\author{
Neha Sharma ${ }^{1}$ and Vishala Patnam ${ }^{2}$ \\ Vasantrao Naik Marathwada Krish Vidyapeeth, Parbhani - 431402
}

Abstract: Irrespective of SES groups fifty five percent of the University female students assessed to have middle
level self esteem followed by high level self esteem (24.50\%) and low level self esteem (24.50\%). There was a
significant association between the self esteem levels of the University female students and the ratings about
their physical appearance, physique and body language in both low and middle SES groups
Key words: Self esteem, Low SES, Middle SES, Physique, Body Language, Special Abilities.

Self esteem is the total of the person's desired mental and physical characteristics as well as the person's perceived worthiness (Lawrence, 1996). Self-esteem is a basic human need or motivation. It is divided into two aspects, the esteem for oneself (self-love, self-confidence, skill, aptitude, etc.), and respect one receives from other people (recognition, success, etc.) Bardon, defined self esteem as the disposition to experience oneself as being competent to cope with the basic challenges of life, feeling worthy and happy. Self-esteem is based on both the descriptive and evaluative self-related statements. Self-esteem is two words compounded into one. Separate them, and the meaning of the larger term comes clear. Self is a descriptive concept: By what specific characteristics do I identify who am I? Esteem is an evaluative concept. How do I judge the value of who am I? Self-esteem has to do with how a person identifies and evaluates self. Self-esteem is all about how much one feels worthiness of oneself - and how much one feels other people's value for self. Self-esteem is important because feeling good about oneself can affect one's mental health and how one behaves. People with high selfesteem know themselves well. People with high self-esteem usually feel more in control of their lives and know their own strengths and weaknesses. These behaviours include isolating oneself from others, feeling a sense of rejection and detachment, alienation, along with increased dissatisfaction with current social relationships. Hence self esteem is something that everyone definitely needs for leading quality and happy life. In every era this mysterious self esteem topic always attracts the attention of researchers for findings out the changing trends in its development and influencing factors. So it was felt necessary to assess the self esteem of University female students and its relation with their selected physical features and aspects.

\section{Materials and Methods}

A sample of 200 University female students were chosen at random from the 4 colleges of Vasantrao Naik Marathwada Krishi Vidyapeeth Parbhani (MS). Out of the 200 female students, 100 were from the middle SES group and the remaining 100 were from the low SES group. The age group of the students ranged between 17 yrs and 24 yrs. The Self-esteem Scale for Women developed by Kapadiya and Verma was administered on them for assessing their self esteem levels. Kuppuswamy's Socio-economic status scale for urban population revised by Patnam (2010) was used to assess the socio-economic status of sample students. A structured cum open ended interview schedule was developed to elicit the information related to students' background and various aspects of the life.

\section{Results and Discussions}

Fifty five percent of University female students assessed to have middle level self esteem followed by high level self esteem (24.50\%) and low level self esteem (24.50\%) irrespective of SES groups. 

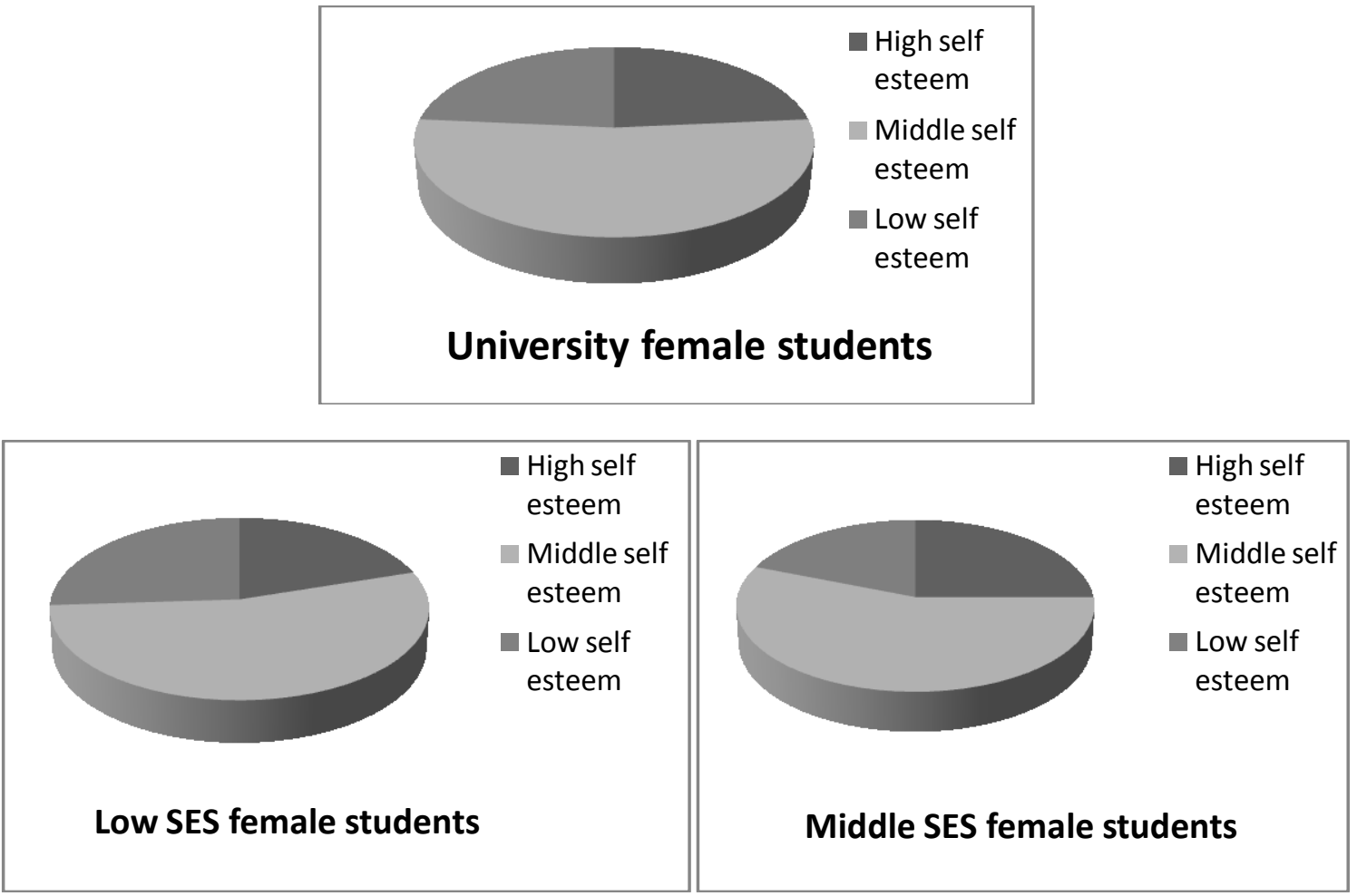

Fig 1 Comparison of self esteem levels of University female students based on their SES

Fifty four to fifty six percent of them irrespective of their SES were rated as having middle level of self esteem female students as being got secured 86-106 score followed by low level self esteem female students (19-26) for having got secured 41-85 score and high level self esteem female students (20-25\%) for having got secured 107-123 score. These results are in the line with the research findings of Patnam et al (2007). These results are also in agreement with general notion that majority of the Indian students and women develop middle level of self esteem due to various socio-economic factors.

Table 1 Comparison of self esteem levels of undergraduate female students with their ratings about physical appearance

\begin{tabular}{|c|c|c|c|c|c|c|c|c|c|c|c|c|}
\hline \multirow{3}{*}{$\begin{array}{c}\text { SE } \\
\text { levels } \\
\text { of the } \\
\text { students }\end{array}$} & \multicolumn{8}{|c|}{ SES, appearance and percentage of students (100) } & \multirow{2}{*}{\multicolumn{4}{|c|}{$Z$ values }} \\
\hline & \multicolumn{4}{|c|}{ Low SES (50) } & \multicolumn{4}{|c|}{ Middle SES (50) } & & & & \\
\hline & $\begin{array}{l}\text { Very } \\
\text { pretty }\end{array}$ & Pretty & $\begin{array}{c}\text { Norma } \\
1\end{array}$ & Poor & $\begin{array}{l}\text { Very } \\
\text { pretty }\end{array}$ & Pretty & $\begin{array}{c}\text { Norma } \\
\text { l }\end{array}$ & Poor & a vs e & b vs f & $\begin{array}{c}\text { c vs } \\
\text { g }\end{array}$ & $\begin{array}{c}d v s \\
\text { h }\end{array}$ \\
\hline $\begin{array}{c}\text { High } \\
\text { (12),(18) }\end{array}$ & $\begin{array}{c}50.00 \\
(6) \\
\end{array}$ & $\begin{array}{c}41.66 \\
(5) \\
\end{array}$ & $\begin{array}{c}08.33 \\
(1) \\
\end{array}$ & - & $\begin{array}{c}50.00 \\
(9) \\
\end{array}$ & $\begin{array}{c}50.00 \\
(9) \\
\end{array}$ & - & - & - & $0.48^{\mathrm{NS}}$ & - & - \\
\hline $\begin{array}{c}\text { Middle } \\
\text { (22),(22) }\end{array}$ & $\begin{array}{c}54.54 \\
(12)\end{array}$ & $\begin{array}{c}31.81 \\
(7)\end{array}$ & $\begin{array}{c}13.63 \\
(3)\end{array}$ & - & $\begin{array}{c}63.63 \\
(14)\end{array}$ & $\begin{array}{c}36.36 \\
(8)\end{array}$ & - & - & $0.60^{\mathrm{NS}}$ & $0.35^{\mathrm{NS}}$ & - & - \\
\hline $\begin{array}{c}\text { Low } \\
(16),(10)\end{array}$ & - & $\begin{array}{c}18.75 \\
(3)\end{array}$ & $\begin{array}{c}18.75 \\
(3)\end{array}$ & $\begin{array}{c}62.50 \\
(10)\end{array}$ & $\begin{array}{c}20.00 \\
(2)\end{array}$ & - & $\begin{array}{c}40.00 \\
(4)\end{array}$ & $\begin{array}{c}40.00 \\
(4)\end{array}$ & - & - & 1.20 & $\begin{array}{c}1.11 \\
\text { NS }\end{array}$ \\
\hline
\end{tabular}

Statistical analysis results of table 1 within self esteem levels Figures in parentheses indicate number of female students

\begin{tabular}{|c|c|c|c|c|c|c|c|c|}
\hline \multirow{3}{*}{$\begin{array}{c}\text { Self esteem } \\
\text { levels }\end{array}$} & \multicolumn{8}{|c|}{$Z$ values } \\
\hline & \multicolumn{4}{|c|}{ Low SES } & \multicolumn{4}{|c|}{ Middle SES } \\
\hline & $\begin{array}{l}\text { Very } \\
\text { pretty }\end{array}$ & Pretty & Normal & Poor & $\begin{array}{l}\text { Very } \\
\text { pretty }\end{array}$ & Pretty & Normal & Poor \\
\hline $\begin{array}{l}\text { High vs } \\
\text { Middle } \\
\end{array}$ & $0.22^{\mathrm{NS}}$ & $\begin{array}{c}0.57 \\
\text { NS }\end{array}$ & $0.47^{\mathrm{NS}}$ & -- & $0.83^{\text {ŇS }}$ & $0.89^{\mathrm{NS}}$ & -- & -- \\
\hline $\begin{array}{l}\text { Middle vs } \\
\text { Low }\end{array}$ & $3.46^{* *}$ & $\begin{array}{c}0.94 \\
\text { NS }\end{array}$ & $0.41^{\mathrm{NS}}$ & $5.99 * *$ & $2.63 *$ & $3.51 * *$ & $2.28 * *$ & $2.28 * *$ \\
\hline High vs Low & $5.08 * *$ & $\begin{array}{c}1.34 \\
\text { NS }\end{array}$ & $0.80^{\mathrm{NS}}$ & $4.03 * *$ & $1.73^{\mathrm{NS}}$ & $4.24 * *$ & $2.28 * *$ & $2.28 * *$ \\
\hline
\end{tabular}

NS- Non significant $*$-Significant at $5 \%$ level $* *$-Significant at $1 \%$ level

Table 1 indicates the comparison of self esteem levels of UG female students with their ratings about physical appearance based on their SES groups. Irrespective of the SES groups of the female students, it is obvious from 
the results that 50-63 percent of UG female students having high and middle levels of self esteem rated themselves as being very pretty with respect to physical appearance, while 40-62 percent of the low level self esteem UG female students rated themselves as being poor in physical appearance. Eight to Fourteen percent of the low SES group UG female students having high and middle levels of self esteem rated themselves as being normal in physical appearance while it was nil percent in middle SES group. Forty percent of the low level self esteem female students in middle SES group rated themselves as being normal. Significantly a higher percentage of the high and middle levels of self esteem female students found to have rated themselves either as very pretty or as pretty as compared to their counterpart to their counterparts having low level of self esteem in both the SES groups which indicates that physical appearance of female students played a pivotal role in raising their levels of self esteem.

Table 2 indicates the comparison of self esteem levels of PG female students with their ratings about physical appearance. Irrespective of the SES groups, it is obvious from the results that 50-57 percent PG female students having high and middle levels of self esteem rated themselves as being very pretty while $60-66$ percent of the low level self esteem female students rated themselves as having poor physical appearance. However in the low SES group, 20-25 percent PG female students having high middle and low levels of self esteem rated themselves as being normal while it was 11-22 percent for middle and low levels self esteem female students in middle SES group. It is clear from the results that there is a significant relationship between the self esteem levels of University female students and their own ratings about their physical appearance. These results are in line with the findings of Erin and Bornstein (2009), David Mellor (2010).

Table 2 Comparison of self esteem of postgraduate female students with their ratings about physical appearance

\begin{tabular}{|c|c|c|c|c|c|c|c|c|c|c|c|c|}
\hline \multirow{3}{*}{$\begin{array}{c}\text { SE } \\
\text { levels } \\
\text { of } \\
\text { students }\end{array}$} & \multicolumn{8}{|c|}{ SES, physical appearance and percentage of the students (100) } & \multirow{2}{*}{\multicolumn{4}{|c|}{$\mathrm{Z}$ values }} \\
\hline & \multicolumn{4}{|c|}{ Low SES (50) } & \multicolumn{4}{|c|}{ Middle SES (50) } & & & & \\
\hline & $\begin{array}{l}\text { Very } \\
\text { pretty }\end{array}$ & $\begin{array}{c}\text { Prett } \\
y\end{array}$ & $\begin{array}{c}\text { Norm } \\
\text { al }\end{array}$ & $\begin{array}{c}\text { Poo } \\
\mathbf{r}\end{array}$ & $\begin{array}{l}\text { Very } \\
\text { pretty }\end{array}$ & Pretty & $\begin{array}{l}\text { Nor } \\
\text { mal }\end{array}$ & Poor & $\begin{array}{c}\text { a vs } \\
\text { e }\end{array}$ & $\begin{array}{c}\text { b vs } \\
\text { f }\end{array}$ & $\begin{array}{c}\text { c vs } \\
\text { g }\end{array}$ & $\begin{array}{c}\text { d vs } \\
\text { h }\end{array}$ \\
\hline $\begin{array}{l}\text { High } \\
(8),(7)\end{array}$ & $\begin{array}{c}50.00 \\
(4)\end{array}$ & $\begin{array}{c}25.00 \\
(2)\end{array}$ & $\begin{array}{c}25.00 \\
(2)\end{array}$ & - & $\begin{array}{c}57.14 \\
(4)\end{array}$ & $\begin{array}{c}42.85 \\
(3)\end{array}$ & - & - & $\begin{array}{c}0.27 \\
\text { NS }\end{array}$ & $\underset{\text { NS }}{0.70}$ & - & - \\
\hline $\begin{array}{l}\text { Middle } \\
(32),(34)\end{array}$ & $\begin{array}{c}50.00 \\
(16)\end{array}$ & $\begin{array}{c}25.00 \\
(8)\end{array}$ & $\begin{array}{c}12.50 \\
(4)\end{array}$ & $\begin{array}{c}12.5 \\
0 \\
(4)\end{array}$ & $\begin{array}{c}35.29 \\
(12)\end{array}$ & $\begin{array}{c}52.94 \\
(18)\end{array}$ & $\begin{array}{c}11.76 \\
(4)\end{array}$ & - & $\begin{array}{c}1.24 \\
\text { NS }\end{array}$ & $\begin{array}{c}2.34 \\
*\end{array}$ & 0.12 & - \\
\hline $\begin{array}{c}\text { Low } \\
(10),(9)\end{array}$ & - & $\begin{array}{c}20.00 \\
(2)\end{array}$ & $\begin{array}{c}20.00 \\
(2)\end{array}$ & $\begin{array}{c}60.0 \\
0 \\
(6) \\
\end{array}$ & - & $\begin{array}{c}11.11 \\
(1)\end{array}$ & $\begin{array}{c}22.22 \\
(2)\end{array}$ & $\begin{array}{c}66.66 \\
(6)\end{array}$ & - & $\begin{array}{c}0.54 \\
\text { NS }\end{array}$ & $\begin{array}{c}0.10 \\
\text { NS }\end{array}$ & $\begin{array}{c}0.27 \\
\text { NS }\end{array}$ \\
\hline
\end{tabular}

Statistical analysis results of table 2 within self esteem levels

\begin{tabular}{|c|c|c|c|c|c|c|c|c|}
\hline \multirow{3}{*}{$\begin{array}{c}\text { Self esteem } \\
\text { levels }\end{array}$} & \multicolumn{8}{|c|}{$Z$ values } \\
\hline & \multicolumn{4}{|c|}{ Low SES } & \multicolumn{4}{|c|}{ Middle SES } \\
\hline & $\begin{array}{l}\text { Very } \\
\text { pretty }\end{array}$ & Pretty & Normal & Poor & $\begin{array}{l}\text { Very } \\
\text { pretty }\end{array}$ & Pretty & Normal & Poor \\
\hline $\begin{array}{l}\text { High vs } \\
\text { Middle }\end{array}$ & & -- & $0.79^{\mathrm{NS}}$ & $2.08 *$ & $1.07^{\mathrm{NS}}$ & $0.48^{\mathrm{NS}}$ & $2.04 *$ & -- \\
\hline $\begin{array}{c}\text { Middle vs } \\
\text { Low }\end{array}$ & $5.65 * *$ & $0.33^{\mathrm{NS}}$ & $0.57^{\mathrm{NS}}$ & $2.90 * *$ & $4.27 * *$ & $3.03 * *$ & $0.74^{\mathrm{NS}}$ & $4.17 * *$ \\
\hline $\begin{array}{c}\text { High vs } \\
\text { Low }\end{array}$ & $2.82 * *$ & 0.25 & $0.25^{\mathrm{NS}}$ & $3.87 * *$ & $1.94 *$ & $1.45^{\mathrm{NS}}$ & $1.59^{\mathrm{NS}}$ & $4.17 * *$ \\
\hline
\end{tabular}

Figures in parentheses indicate number of female students

NS- Non significant *-Significant at 5\% level $* *$-Significant at $1 \%$ level

\begin{tabular}{|c|c|c|c|c|c|c|}
\hline \multirow{2}{*}{$\begin{array}{c}\text { SE levels } \\
\text { of students }\end{array}$} & \multicolumn{2}{|c|}{ SES, physique and percentage of the students (100) } & \multicolumn{2}{c|}{ Z Values } \\
\cline { 2 - 6 } & Good & Not good & Good & Not good & a vs c & b vs d \\
\cline { 2 - 6 } & $66.66(8)$ & $33.33(4)$ & $88.88(16)$ & $11.11(2)$ & $1.40^{\mathrm{NS}}$ & $1.42^{\mathrm{NS}}$ \\
\hline $\begin{array}{c}\text { High } \\
(\mathbf{1 2}),(\mathbf{1 8})\end{array}$ & $81.81(18)$ & $18.18(4)$ & $77.27(17)$ & $22.72(5)$ & $0.32^{\mathrm{NS}}$ & $0.33^{\mathrm{NS}}$ \\
\hline $\begin{array}{c}\text { Middle } \\
(\mathbf{2 2}),(\mathbf{2 2})\end{array}$ & $31.25(5)$ & $68.75(11)$ & $20.00(2)$ & $80.00(8)$ & $0.64^{\mathrm{NS}}$ & $0.69^{\mathrm{NS}}$ \\
\hline $\begin{array}{c}\text { Low } \\
(\mathbf{1 6}),(\mathbf{1 0})\end{array}$ & & & & & \\
\hline
\end{tabular}


Table 3 Comparison of self esteem levels of undergraduate female students with ratings about physique Statistical analysis results of table 3 within self esteem levels

\begin{tabular}{|c|c|c|c|c|}
\hline \multirow{2}{*}{ Self esteem levels } & \multicolumn{3}{|c|}{ Z values } \\
\cline { 2 - 5 } & \multicolumn{2}{|c|}{ Low SES } & \multicolumn{2}{c|}{ Middle SES } \\
\cline { 2 - 5 } & Good & Not Good & Good & Not Good \\
\hline High vs Middle & $0.93^{\mathrm{NS}}$ & $0.94^{\mathrm{NS}}$ & $0.93^{\mathrm{NS}}$ & $0.95^{\mathrm{NS}}$ \\
\hline Middle vs Low & $3.50^{* *}$ & $3.50^{* *}$ & $3.67^{* *}$ & $3.75^{* *}$ \\
\hline High vs Low & $1.95^{*}$ & $1.95^{*}$ & $4.59^{* *}$ & $4.71^{* *}$ \\
\hline
\end{tabular}

Figures in parentheses indicate number of female students

NS- Non significant $*$-Significant at $5 \%$ level $* *$-Significant at $1 \%$ level

Table 3 indicates the comparison of self esteem levels of UG female students with their ratings about their physique on the based on SES groups. It is clear from the results that 67-88 percent of the high and middle levels of self esteem UG female students rated their physique as being good in the both SES (low and middle) groups. On the other hand 69-80 percent of the low level self esteem UG female students rated their physique as being not good. On the other hand 69-80 percent of the low level self esteem UG female students rated their physique as being not good. No significant differences were found in the self esteem levels of UG students' ratings about their physique based on their SES groups.

Table 4 indicates comparison of the self esteem levels of PG female students with their ratings about their physique based on SES groups. It is obvious from the results that 56-100 percent of PG the female students having the high and middle levels of self esteem rated their physique as being good in the both SES groups, while 43-100 percent PG female students having middle and low level of self esteem rated their physique as being not good in both SES groups. On the other hand, 14-21 percent of the PG female students with high and middle levels of self esteem rated their physique as being not good. A higher percentage of the low SES group PG female students having middle level of self esteem found to have rated their physique as good as compared to their counterparts in middle SES group. Results indicate that PG female students' opinions about their own physique significantly influenced their levels of self esteem. These findings are in line with the results of the research studies carried out by Hayes et al (1999), Erin and Bornstein (2009), David Mellor (2010).

Table 4 Comparison of self esteem levels of postgraduate female students with their ratings about physique

\begin{tabular}{|c|c|c|c|c|c|c|}
\hline \multirow{3}{*}{$\begin{array}{c}\text { SE levels } \\
\text { of } \\
\text { students }\end{array}$} & \multicolumn{4}{|c|}{ SES, physique and percentage of the students (100) } & \multirow{2}{*}{\multicolumn{2}{|c|}{ Z Values }} \\
\hline & \multicolumn{2}{|c|}{ Low SES(50) } & \multicolumn{2}{|c|}{ Middle SES (50) } & & \\
\hline & Good & Not good & Good & Not good & a vs c & b vs d \\
\hline $\begin{array}{l}\text { High } \\
(8),(7)\end{array}$ & $100(8)$ & - & $85.71(6)$ & $14.28(1)$ & $1.11^{\mathrm{NS}}$ & - \\
\hline $\begin{array}{c}\text { Middle } \\
\text { (32),(34) }\end{array}$ & $56.25(18)$ & $43.75(14)$ & $79.41(27)$ & $20.58(7)$ & $2.05^{*}$ & $2.06^{*}$ \\
\hline $\begin{array}{c}\text { Low } \\
(10),(9)\end{array}$ & - & $100(10)$ & - & $100(9)$ & - & - \\
\hline
\end{tabular}

Statistical analysis results of table 4 within self esteem levels

\begin{tabular}{|c|c|c|c|c|}
\hline \multirow{2}{*}{ Self esteem levels } & \multicolumn{3}{|c|}{$Z$ values } \\
\cline { 2 - 5 } & \multicolumn{2}{|c|}{ Low SES } & Good & Not Good \\
\cline { 2 - 5 } & Good & Not Good & $0.39^{\mathrm{NS}}$ & $0.40^{\mathrm{NS}}$ \\
\hline High vs Middle & $5.01^{* *}$ & $4.91^{* *}$ & $11.30^{* *}$ & $11.66^{* *}$ \\
\hline Middle vs Low & $6.38^{* *}$ & $6.51^{* *}$ & $6.38^{* *}$ & $6.55^{* *}$ \\
\hline High vs Low & -- & -- & & \\
\hline
\end{tabular}

Figures in parentheses indicate number of female students

NS- Non significant *-Significant at 5\% level $* *$-Significant at $1 \%$ level

Table 5 Comparison of self esteem levels of undergraduate female students with peers' feedback about body language

\begin{tabular}{|c|c|c|c|c|c|c|c|c|c|}
\hline \multirow{3}{*}{$\begin{array}{c}\text { Self esteem levels of } \\
\text { students }\end{array}$} & \multicolumn{6}{|c|}{ SES, body language and percentage of the students (100) } & \multirow{2}{*}{\multicolumn{3}{|c|}{ Z Values }} \\
\hline & \multicolumn{3}{|c|}{ Low SES (50) } & \multicolumn{3}{|c|}{ Middle SES (50) } & & & \\
\hline & Good & Average & Poor & Good & Average & Poor & a vs d & b vs e & c vs f \\
\hline $\begin{array}{c}\text { High } \\
(12),(18)\end{array}$ & $66.66(8)$ & $25.00(3)$ & $08.33(1)$ & $77.77(14)$ & $22.22(4)$ & - & $0.65^{\mathrm{NS}}$ & $0.18^{\mathrm{NS}}$ & - \\
\hline $\begin{array}{c}\text { Middle } \\
(22),(22)\end{array}$ & $45.40(10)$ & $36.30(8)$ & $18.10(4)$ & $81.80(18)$ & $09.09(2)$ & $09.09(2)$ & $2.66^{*}$ & $2.26^{*}$ & $0.88^{\mathrm{NS}}$ \\
\hline $\begin{array}{c}\text { Low } \\
(16),(10)\end{array}$ & $25.00(4)$ & $50.00(8)$ & $25.00(4)$ & $20.00(2)$ & $40.00(4)$ & $40.00(4)$ & $0.30^{\mathrm{NS}}$ & $0.50^{\mathrm{NS}}$ & $0.79^{\mathrm{NS}}$ \\
\hline
\end{tabular}


From table 5 it is interesting to note that both low and middle SES groups majority of the high level self esteem UG female students (67-78\%) received good feedback about their body language from their peers, while 45-81 percent middle level self esteem UG female students received average feedback about their body language from their peers. Forty to fifty percent low level self esteem UG female students received average feedback about their body language from their peers followed by middle level self esteem UG female students (9-36\%) and high level self esteem UG female students (22-25\%). On the other hand, only 8 percent in low SES group and none of the middle SES group high self esteem UG female students received poor feedback about their body language from their peers, while 9-40 percent middle and low levels of self esteem UG students received poor feedback about their body language. Results indicate that there is significant association between self esteem levels of female students and feedback received about their body language from their peers.

Statistical analysis results of table 5 within self esteem levels

\begin{tabular}{|c|c|c|c|c|c|c|}
\hline \multirow[t]{3}{*}{ Self esteem levels } & \multicolumn{6}{|c|}{$\mathrm{Z}$ values } \\
\hline & \multicolumn{3}{|c|}{ Low SES } & \multicolumn{3}{|c|}{ Middle SES } \\
\hline & Good & Average & Poor & Good & Average & Poor \\
\hline High vs Middle & $1.21^{\mathrm{NS}}$ & $0.68^{\mathrm{NS}}$ & $0.88^{\mathrm{NS}}$ & $0.30^{\mathrm{NS}}$ & $1.12^{\mathrm{NS}}$ & $1.47^{\mathrm{NS}}$ \\
\hline Middle vs Low & $1.31^{\mathrm{NS}}$ & $0.86^{\mathrm{NS}}$ & $0.51^{\mathrm{NS}}$ & $4.02 * *$ & $1.86^{*}$ & $1.86^{\mathrm{NS}}$ \\
\hline High vs Low & $2.35^{*}$ & $1.41^{\mathrm{NS}}$ & $1.27^{\mathrm{NS}}$ & $3.54 * *$ & $0.98^{\mathrm{NS}}$ & $2.80^{* *}$ \\
\hline
\end{tabular}

Figures in parentheses indicate number of female students

NS- Non significant *-Significant at 5\% level $* *$-Significant at $1 \%$ level

Table 6 Comparison between self esteem levels of postgraduate female students with peers' feedback about their body language

\begin{tabular}{|c|c|c|c|c|c|c|c|c|c|}
\hline \multirow{3}{*}{$\begin{array}{c}\text { Self esteem } \\
\text { levels of } \\
\text { students }\end{array}$} & \multicolumn{6}{|c|}{ SES, body language and percentage of the students (100) } & \multirow{2}{*}{\multicolumn{3}{|c|}{ Z Values }} \\
\hline & \multicolumn{3}{|c|}{ Low SES (50) } & \multicolumn{3}{|c|}{ Middle SES (50) } & & & \\
\hline & Good & Average & Poor & Good & Average & Poor & a vs d & b vs e & c vs f \\
\hline $\begin{array}{c}\text { High } \\
(8),(7)\end{array}$ & $75.00(6)$ & $12.50(1)$ & $12.50(1)$ & $85.70(6)$ & $14.28(1)$ & - & $0.48^{\mathrm{NS}}$ & $0.11^{\mathrm{NS}}$ & - \\
\hline $\begin{array}{c}\text { Middle } \\
(32),(34)\end{array}$ & $56.25(18)$ & $31.20(10)$ & $12.50(4)$ & $17.64(6)$ & $52.90(18)$ & $29.40(10)$ & $0.32^{\mathrm{NS}}$ & $1.77^{\mathrm{NS}}$ & $1.75^{\mathrm{NS}}$ \\
\hline $\begin{array}{c}\text { Low } \\
(\mathbf{1 0}),(9)\end{array}$ & - & $20.00(2)$ & $80.00(8)$ & - & $44.44(4)$ & $55.55(5)$ & - & $1.15^{\mathrm{NS}}$ & $1.19^{\mathrm{NS}}$ \\
\hline
\end{tabular}

Statistical analysis results of table 6 within self esteem levels

\begin{tabular}{|c|c|c|c|c|c|c|}
\hline \multirow[t]{3}{*}{ Self esteem levels } & \multicolumn{6}{|c|}{$Z$ values } \\
\hline & \multicolumn{3}{|c|}{ Low SES } & \multicolumn{3}{|c|}{ Middle SES } \\
\hline & Good & Average & Poor & Good & Average & Poor \\
\hline High vs Middle & $1.07^{\mathrm{NS}}$ & $1.34^{\mathrm{NS}}$ & -- & $4.54 * *$ & $2.42 *$ & -- \\
\hline Middle vs Low & $6.38 * *$ & $0.73^{\mathrm{NS}}$ & $4.89 * *$ & -- & $0.42^{\mathrm{NS}}$ & $1.41^{\mathrm{NS}}$ \\
\hline High vs Low & $4.89 * *$ & $0.46^{\mathrm{NS}}$ & $3.97 * *$ & -- & $1.36^{\mathrm{NS}}$ & -- \\
\hline
\end{tabular}

Figures in parentheses indicate number of female students

NS- Non significant *-Significant at 5\% level $* *$-Significant at $1 \%$ level

From the table 6 it is obvious that both the low and middle SES groups, majority (75-85\%) of the high level self esteem PG female students received good feedback about their body language from their peers followed by middle self esteem PG students (17-56\%), while in both SES groups 12-14 percent of PG female students having high level self esteem received average feedback. Twenty to fifty percent PG female students having middle and low level of self esteem in the both SES groups received the average feedback from the peers about their body language. However, twelve percent high level self esteem students of the low SES group found to have received poor feedback about their body language from the peers. On the other hand 12-80 percent PG female students having middle and low levels of self esteem in both SES groups received poor feedback about their body language from peers. Fig 8 and the statistical analysis computed between self esteem levels of PG female students and the feedback they received about their body language from peers clearly indicate that there is a significant difference between self esteem levels of PG female students and their body language. These results were in line with the findings reported by Ikeda and Nawarski (1992), Hyes et al (1999). 


\section{References}

[1]. Brookover, Thomas and Patterson 1985 In website http://bsos.umd.edu/socy/Rosenberg.html

[2]. Camphell J., Krueger J.I., Vohs K.D. and Baumeister R.F. 2003 Cited in the article on Does high self esteem cause better performance,

[3]. Covington M.V. 1989 Self-esteem and Failure in school. The social importance of self-esteem. U.C. press, Berkeley, CA, 155165 .

[4]. David mellor, Mathew feeler-Tyszkiewiez marita P. McCabe, Lina A. Ricciardelli 2010,Body Image and Self Esteem Across Age and Gender: A Short-Term Longitudinal study Self identity, journal of sex roles ,63:9-10, 672-681.

[5]. Erin T. Barker, Marc H. Bornstein 2009, Global Self-Esteem, Appearance Satisfaction and Self Reported Dieting in Adolescence, 30:2, 205-224.

[6]. Hayes S.D., Crocker, Kowalski K.C. 1999 Gender differences in physical self -perception, global self esteem and physical activity: eveluvation of the physical self eseteem profile model, J of Sport Behaviour, 1, 1-14.

[7]. Holly W. 1987 Self-Esteem: Does It Contribute to Students' Academic Success? Eugene, OR: Oregne School Study Council, Univ. of Oregon.

[8]. Ikeda Joanne, Naworski Priscilla 1992, Am I fat? Helping young children Accept Differences in Body size.

[9]. Lawrence, 1996 In website D Lawrence - books.google.com

[10]. Scheirer M. and Krant R. 1979 Increasing educational achievement via self-concept change. Review of Educational research. 49, 131-150.

[11]. Shinde V.D. and Patnam V.N. (2007) Influence of Parenting Practices and Prenatal History on Self esteem on Rural Girls. Asian J. of Psychology. 